Disponible en ligne sur

ScienceDirect

www.sciencedirect.com
Elsevier Masson France

EM|consulte

www.em-consulte.com

Original article

\title{
New aspects of Neoproterozoic-Cambrian transition in the Corumbá region (state of Mato Grosso do Sul, Brazil)
}

\author{
Nouvelles perspectives sur la transition Néoprotérozoïque-Cambrien dans la région \\ de Corumbá, Mato Grosso do Sul, Brésil
}

\author{
Detlef H.G. Walde a,*, Dermeval A. do Carmo ${ }^{a}$, Edi M. Guimarães ${ }^{a}$, Lucieth Cruz Vieira ${ }^{a}$, \\ Bernd-D. Erdtmann ${ }^{\mathrm{b}}$, Evelyn A.M. Sanchez ${ }^{\mathrm{a}}$, Rodrigo R. Adorno ${ }^{\mathrm{c}}$, Thais C. Tobias ${ }^{\mathrm{a}}$ \\ a Instituto de Geociências, Universidade de Brasília, Campus Darcy Ribeiro. Instituto Central de Ciências, Ala Central, CEP 70910-900 Brasília, DF Brazil \\ ${ }^{\mathrm{b}}$ Institute of Applied Geosciences, Technical University Berlin, 1, Ernst-Reuter-Platz, 10587 Berlin, Germany

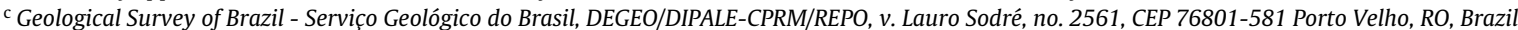

\section{A R T I C L E I N F O}

\section{Article history:}

Received 10 November 2014

Accepted $1^{\text {st }}$ July 2015

Available online $\mathrm{xxx}$

\section{Keywords:}

Ediacaran

Brazil

Corumbá Group

Cloudina

Corumbella

\begin{abstract}
A B S T R A C T
This study aims to update the knowledge about the importance of the late Ediacaran fossil record and geochemical data from Corumbá, State of Mato Grosso do Sul, at the Brazilian-Bolivian border. The Corumbá graben system is located near a triple junction developed above a hot spot of two young (545-480 Ma) Brasiliano provinces: the mostly Bolivian Chiquitos-Tucavaca aulacogen which cuts across the Amazon Craton/Rio Apa Block, and Paraguay Fold Belt. The Neoproterozoic sedimentary cover of South Paraguay Belt starts with the metasediments, diamictites and iron formation of the Jacadigo Group, now related to an end-Cryogenian age. Most remarkable geochemical and paleontological data come from the overlying Corumbá group, mainly from the dolostones with stromatolites of the Bocaina Formation, and limestones with shale and silty intercalations at this group's upper part, in the Tamengo Formation. This last unit contains a fossil assemblage correlated to late Ediacaran fauna. This fauna contains originally substrate-emergent tube-like Corumbella werneri, Cloudina lucianoi and microfossils. Furthermore, the fossils from the Corumbá Group in Brazil and Paraguay represent the most important witnesses for the occurrence of late Ediacaran fossils close to the basal Cambrian boundary in South America. Therefore, the Corumbá region is significant for paleogeographical reasons and, on the other hand, allows insights into the evolution of the oldest skeletonized metazoans. After new research results, the high degree of similarity of the geological facies evolution with other parts of the world (e.g. Yangtze Platform/Southern China, Siberia, Spain and Namíbia) can be demonstrated, where the fragmentation of the Rodinia supercontinent and Neoproterozoic glaciations are also well-documented. The sharp top contact of the shallow marine Tamengo Formation with the laminated black shales (containing rare angular dropstones) of the discordantly overlying Guaicurus Formation indicates that the latter represents a new transgressive glacially influenced marine onlap succession. A Cambrian age of the Guaicurus Shales is not (yet) biostratigraphically verified, however, the underlying fossil record of cloudinids indicates a terminal Ediacaran age for the top of the Tamengo Formation. The microtubular cloudinids are interpreted as dysoxic analogues of recent tubeworms and are suggested to serve as first skeletonized worldwide "index fossils" to delineate the onset of a Phanerozoic-type body fossil vectorial evolutionary pathway. Based on the FAD of cloudinids as marker fossils, a revision of the Precambrian/Cambrian boundary is here advocated. This would avoid placing this important GSSP into the virtually worldwide Nomtsas-Baykonurian glacial hiatus.
\end{abstract}

(c) 2015 Elsevier Masson SAS. All rights reserved.

\footnotetext{
* Corresponding author.

E-mail address: walde.detlef@gmail.com (D.H.G. Walde).
} 
Mots clés :

Ediacarien

Brésil

Groupe Corumbá

Cloudina

Corumbella

\section{R É S U M É}

Cet étude vise à mettre à jour les connaissances sur l'enregistrement fossilifère et les données géochimiques de la période Ediacarienne supérieure à Corumbá, ville de l'état Mato Grosso do Sul, située à la frontière entre le Brésil et la Bolivie. Le système de grabens de Corumbá se trouve à proximité d'un point triple, développé au dessus d'un point chaud, constitué de deux jeunes provinces du Brasiliano (545-480 $\mathrm{Ma}$ ) : l'aulacogène Chiquitos-Tucavacaaulacogen (Bolivien) qui recoupe le Craton Amazonien et le bloc Rio Apa, et la chaîne plissée du Paraguay. La couverture sédimentaire néoprotérozoïque de la portion sud de la chaîne plissée du Paraguay est constituée de la base au sommet par des sédiments métamorphisés, des diamictites et des BIF du Groupe de Jacadigo, aussi dans la ville de Corumbá, actuellement associés à un âge Cryogénien. Cette dernière est recouverte par les sédiments du Groupe de Corumbá constitués de dolomites à stromatolithes de la Formation de Bocaina et des calcaires présentant des intercalations de shale et siltite dans la partie supérieure du Groupe de Corumbá au sein de la Formation de Tamengo. Les résultats géochimiques et paléontologiques les plus notables ont été obtenu sur les sédiments du Groupe de Corumbá. En effet, cette formation, aux environs de la ville de Corumbá, contient une faune édiacarienne. Cette faune contient des fossiles tubulaires comme Corumbella werneri, Cloudina lucianoi ainsi que des microfossiles. De plus, les fossiles du Groupe de Corumbá (au Brésil et au Paraguay) représentent les témoins les plus importants en Amérique du Sud de fossiles de l'Ediacarien terminal, proche de la base du Cambrien. En conséquence, la faune de Corumbá se révèle de la plus grande importance pour des raisons géographiques, géologiques et paleoenvironnementales. Elle permet également d'avoir un aperçu de l'évolution des plus anciens métazoaires à squelette comme, par exemple, les fossiles tubulaires. Au regard de ces nouveaux résultats, le dégré élevé de similitude de l'évolution des successions sédimentaires avec d'autres parties du monde où la fragmentation du supercontinent Rodinia et les glaciations du Néoprotérozoïque sont également bien documentées (par exemple, la Plate-forme Yangtze au Sud de la Chine, la Sibérie, l'Espagne et la Namibie) peut être démontré. Le contact supérieur discordant et brutal de la Formation de Tamengo (sédimentation marine peu profonde) avec la Formation de Guaicurus (schistes noirs contenant de rares dropstones angulaires) correspond au début d'une sédimentation marine transgressive avec influence glaciaire. L'âge Cambrien des schistes de la Formation de Guaicurus n'est pas (encore) bio-stratigraphiquement vérifié, toutefois, les fossiles de cloudinids indiquent un âge Ediacarien pour le top de la Formation de Tamengo. Les fossiles microtubulaires cloudinides sont interprétés comme des analogues des vers tubulaires dysoxiques actuels. Ils sont ainsi proposés pour servir de premier fossile stratigraphique à squelette ayant une répartition mondiale. Ils permettraient de délimiter le début du " Phanerozoic-type body fossil vectorial evolutionary pathway ». Une révision de la limite Précambrien/Cambrien est ici préconisée basée sur la FAD des cloudinides. Cela permettrait d'éviter d'imposer cet important GSSP durant le hiatus des glaciations du Nomtsas-Baykonurian virtuellement présent dans le reste du monde.

두 2015 Elsevier Masson SAS. Tous droits réservés.

\section{Introduction}

In South America, units of Paraguay Fold Belt, mainly those of its southern part, provide the most complete record of the late Ediacaran climatic, biogeochemical and biotic evolution. The Paraguay belt is a late Pan-African-Brasiliano age fold belt in southwestern Brazil, that comprises a southern and a northern branch with similar lithostratigraphy (Gaucher et al., 2003; Boggiani et al., 2010). In the South Paraguay Belt, around the city of Corumbá, in Western Brazil, late Neoproterozoic subhorizontal or tilted cratonic cover rocks lie above the basement of the Amazon Craton-Rio Apa Block. These strata include the Jacadigo Group, which caps inselbergs up to $1200 \mathrm{~m}$ high, and the carbonate-siliciclastic Corumbá Group, which crops out in the surrounding lowlands of the swampy Pantanal peneplain.

The importance of the Jacadigo and Corumbá groups rests in their paleoclimatic and biological context. Both units were deposited in a time interval of profound changes in the paleogeographic configuration due to the break-up of the supercontinent Rodinia, the formation of new shallow waters and the further amalgamation of Gondwana (Li et al., 2013). These events resulted in paleoclimatic changes represented by the alternation of glacial and non-glacial periods in a relatively short time interval, known as Snowball Earth model (Hoffman et al., 1998). At the same time that climatic changes occurred, the ocean chemistry also went through changes, including more available free oxygen (see review in Fedonkin, 2003; Fike et al., 2006; Och and Shields-Zhou, 2012; Mills and Canfield, 2014). Combinations of these factors lead to major biological innovations among multicellular eukaryotes, including the appearance of vendobionts and, later, the appearance of metazoans (e.g. Fike et al., 2006). Part of the Neoproterozoic innovations and peculiar environmental conditions are recorded in the Corumbá region, mainly in the homonymous group (Gaucher et al., 2003; Boggiani et al., 2010; Fairchild et al., 2012; Morais-Soares et al., 2013; Kerber et al., 2013), and thus deserve special attention.

The main goal of this paper is to show an overview of paleogeographic, tectonic and depositional context of the Jacadigo and Corumbá groups, along with new data acquired by the research team of the University of Brasilia, carried out with support by PETROBRAS, concerning isotopic and mineral approaches. Our guest author, Dr. Bernd-D. Erdtmann (Technical University of Berlin) reinterpreted the tube fossil Corumbella werneri (Hahn et al., 1982) and presents the key aspects here. The paleontological record, as well as new chemical and sedimentological aspects of the Corumbá Group, are also presented and compared to the same key terminal Ediacaran units worldwide, like in South China and Namibia.

\section{Geological setting}

Stratigraphical, sedimentological and structural data suggest the following history for the Neoproterozoic sequences around the city of Corumbá, related to the evolution of a graben system. According to Jones (1985) and Walde (1988), the Corumbá region is located on a tectonic triple junction (R-R-R) developed above a hot 

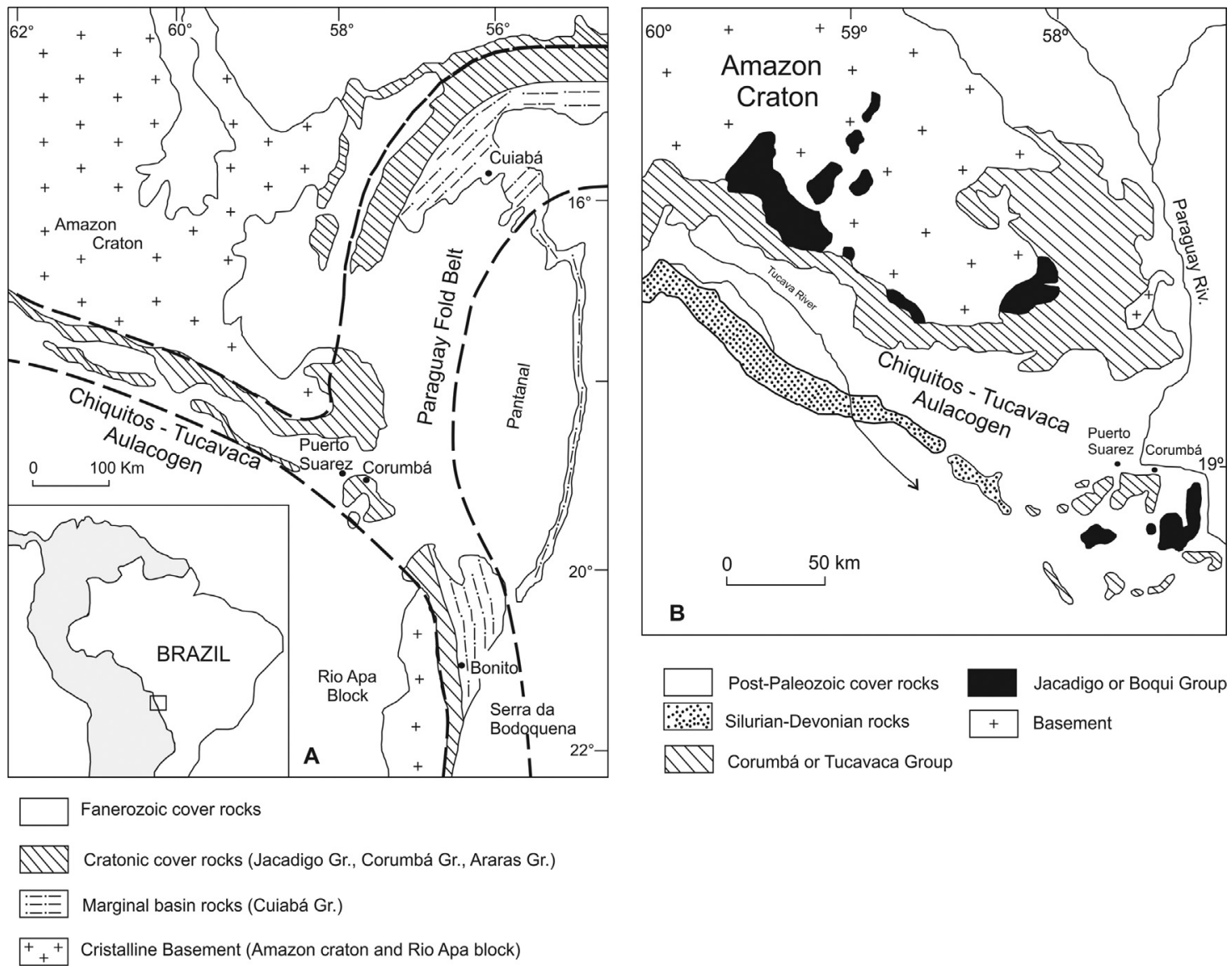

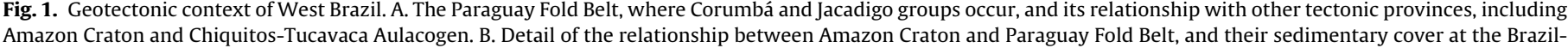
Bolivia border.

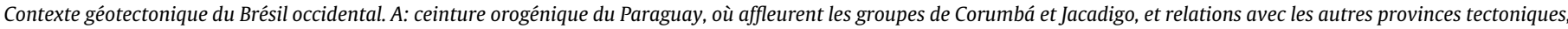

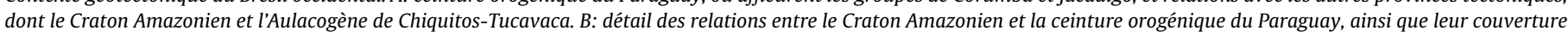
sédimentaire à la frontière entre le Brésil et la Bolivie.

spot, where three basins met, separated by angles of about $120^{\circ}$. They are the North and South Paraguay Basins and the Tucavaca or Chiquitos-Tucavaca Aulacogen. The aulacogen and the Paraguay basins were formed approximately synchronously, with depositional age between 650 and $540 \mathrm{Ma}$ (Babinski et al., 2013).

Just before the Ediacaran Period, extensional tectonics at the southern margin of the Amazonas Craton generated a graben system, known as Corumbá graben (Trompette et al., 1998; Fig. 1). In this context, two lithostratigraphic units were deposited: the Jacadigo and Corumbá groups (Alvarenga et al., 2009; Figs. 2 and 3). Paleogeographic reconstructions confirmed that the Corumbá graben was first filled with sediments of the Jacadigo Group, comprising in the lower part diamictites, volcanogenic material and arkose beds overlain by banded hematite-rich jaspilites with manganese ore intercalations and dropped boulders, as a result of a glacial event.

The depositional age of the upper part of the Jacadigo Group was recently proposed by Piacentini et al. (2013), based on ${ }^{40} \mathrm{Ar} /{ }^{39} \mathrm{Ar}$ dating, and pointed to a $587 \pm 7 \mathrm{Ma}$. New data from Babinski et al. (2013) attested for Puga Formation (equivalent to the lower part of Jacadigo Group, the Urucum Formation) an end-Cryogenian age, although, a Gaskiers age cannot be discharged.

The Corumbá Group was deposited over the diamictites of the Puga Formation and marks the opening of a rift basin. It comprises five formations, including the Cerradinho and Cadiueus formations that outcrop in the southern State of Mato Grosso do Sul, and the Bocaina, Tamengo and Guaicurus formations marking the drift phase, and whose record can be observed over $350 \mathrm{~km}$, from south to north in the State of Mato Grosso do Sul (Boggiani et al., 2010).

The only available dating for the Corumbá Group is a U-Pb zircon age of $543 \pm 3 \mathrm{Ma}$, obtained from volcanic ashes of the Tamengo Formation, which positioned this unit close to the presumed transition to the Cambrian (Boggiani et al., 2010; Babinski et al., 2013). However, its relative age was established from the occurrence of Cloudina fossils, this biozone being well known for the latest Ediacaran.

Deformation and low-grade metamorphism in the region where Jacadigo and Corumbá rocks occur were documented (Trompette et al., 1998). Rocks underwent ductile and brittle deformations represented by a set of tectonic structures (mainly folds, foliations, faults, and fractures) which can be grouped in three main phases $\left(D_{1}-D_{2}-D_{3}\right)$ of a progressive and monocyclic event (Brasiliano cycle) at very low metamorphic grade. The third phase $\left(D_{3}\right)$ is subdivided in $\mathrm{D}_{3 \mathrm{P}}$ and $\mathrm{D}_{3 \mathrm{~T}}$ of coeval crustal shortenings superimposed upon a continental margin already thickened after $D_{1}$ and (mostly) $D_{2}$ deformations. The label $\mathrm{D}_{3 \mathrm{p}}$ stands for the structures due to late crustal shortening associated with the final closure of the oceanic basin precursor of the southern end of the Paraguay Belt, whereas $\mathrm{D}_{3 \mathrm{~T}}$ stands for structures due to late crustal shortening most likely related to the closure of the aborted rift-type basin precursor of the Tucavaca Belt (D’el-Rey personal communication, 2015). 


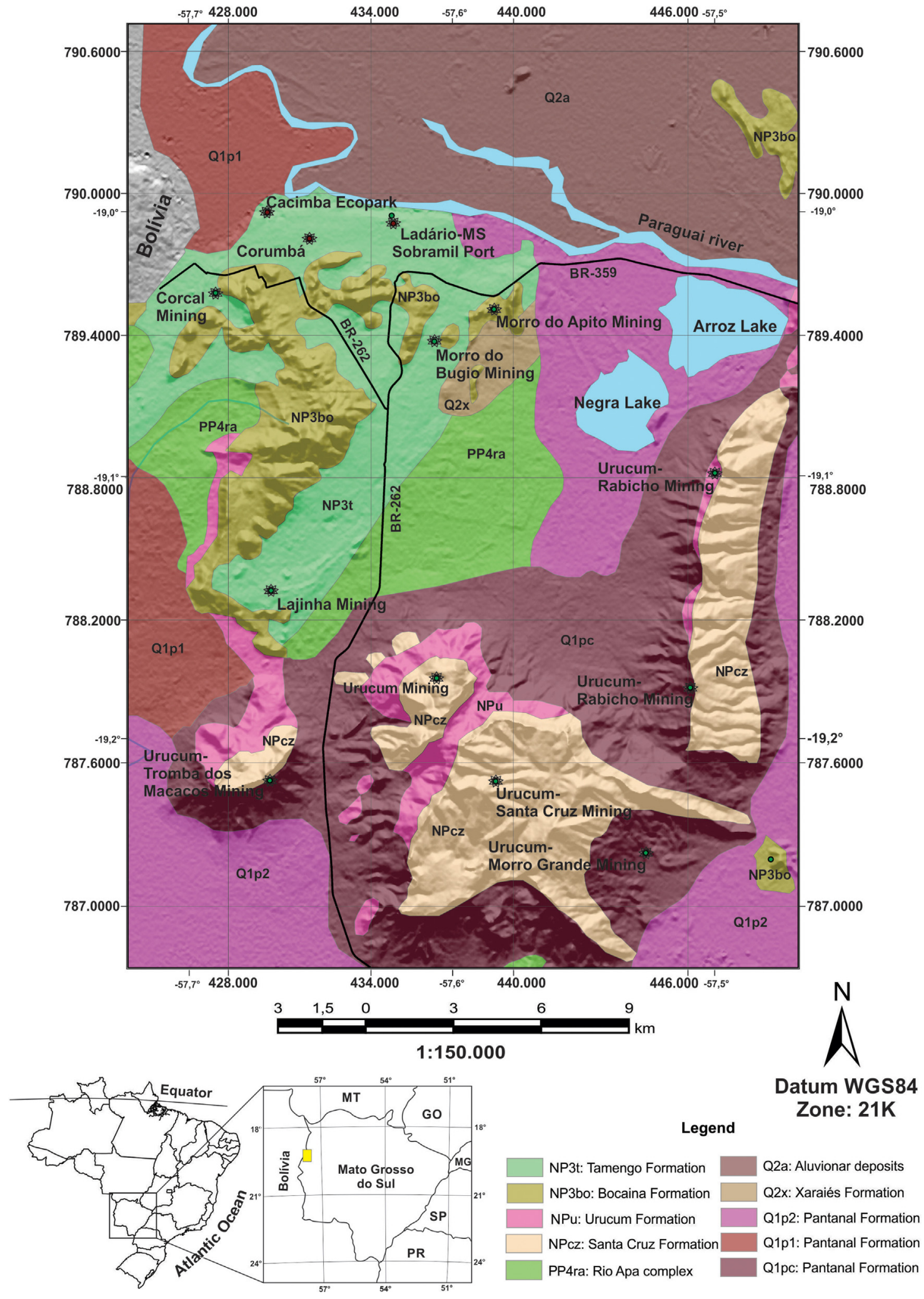

Fig. 2. Regional map showing the cities of Corumbá and Ladário in the State of Mato Grosso do Sul, West Brazil, and the mining areas (quarries) where the fossils studied herein were recovered.

Carte régionale localisant les villes de Corumbá et de Ladário, situées dans l'état du Mato Grosso do Sul, au Brésil et les sites où les fossiles étudiés ici ont été découverts.

\section{Material and methods}

Samples for mineralogical analysis were collected at the Cacimba Cliff in the city of Corumbá, State of Mato Grosso do Sul, where the Tamengo Formation outcrops. The escarpment exposes limestones and intercalated pelitic rocks, as well as the basal and top levels of mudstones. The basal level of mudstone contains a Late Ediacaran fauna represented by Corumbella werneri and 


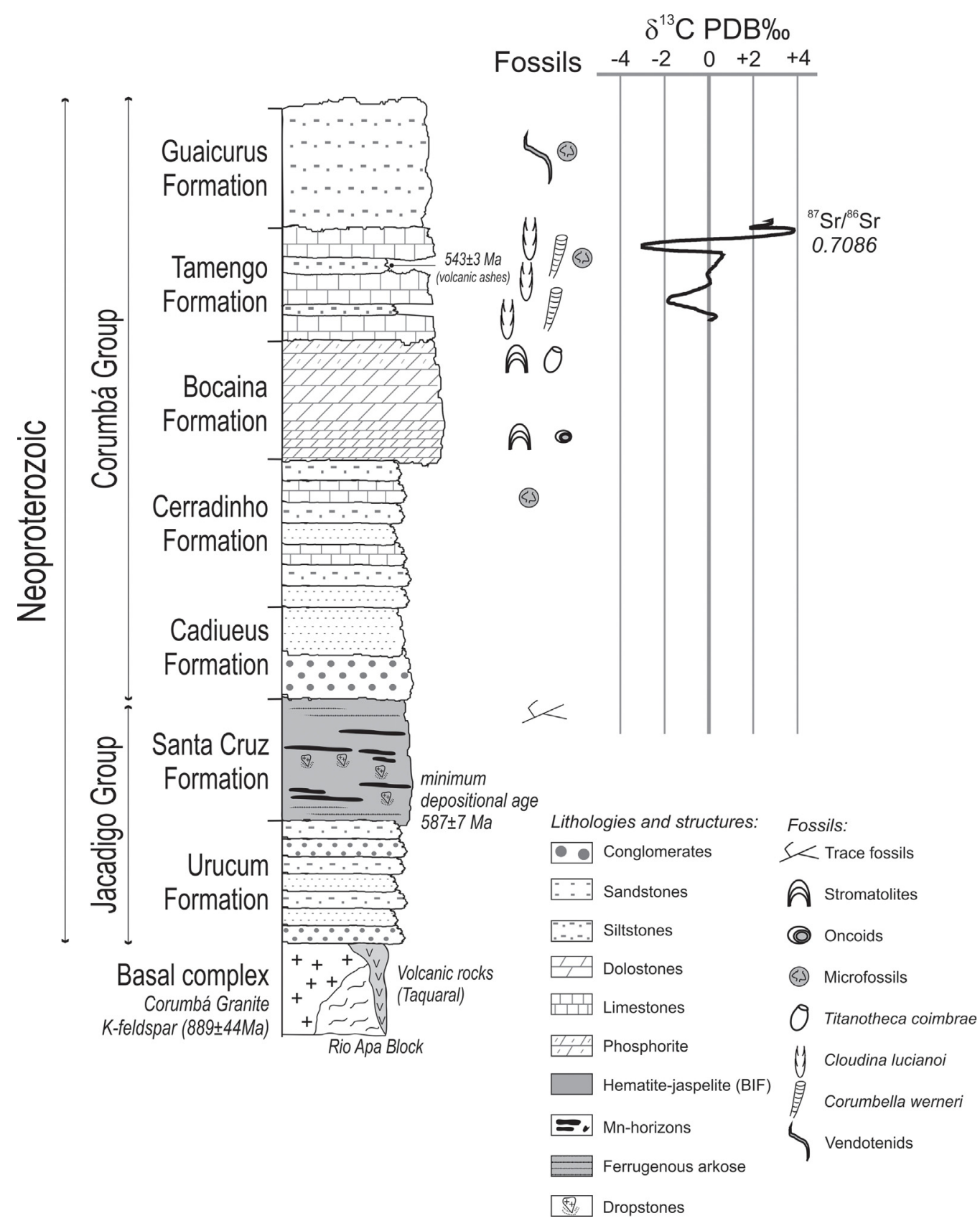

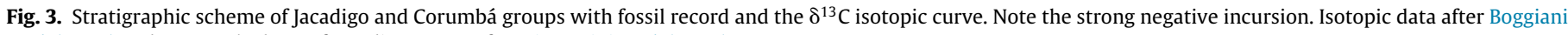
et al. (2010) and ages at the base of Jacadigo Group after Piacentini et al. (2013).

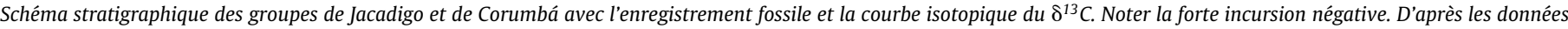
isotopiques de Boggiani et al. (2010) et l'âge de la base du Groupe de Jacadigo obtenu par Piacentini et al. (2013).

Cloudina lucianoi. The mineral composition of the rocks was determined by X-ray diffraction (XRD), whereas structures and textural features were studied through conventional petrographic analysis. All the analyses were performed at the Laboratory of X-ray Diffraction (LDRX), Institute of Geosciences, University of Brasília. Diffraction analyzes were made on Rigaku Ultima IV diffractometer operating with copper tube and nickel filter, under $35 \mathrm{kV}$ and $15 \mathrm{~mA}$, scanning speed of $2^{\circ} / \mathrm{min}$. The scan range was $3-80^{\circ}$ for the total sample and $2-40^{\circ}$ for the clay fraction. The interpretation of the diffractograms was made with the aid of the MDI JADE 9.4, with a database PDF.

Most samples for the carbon and oxygen isotope study were collected at a regular vertical interval of approximately $16 \mathrm{~m}$ also at the Cacimba section. Carbon and oxygen isotope ratios were obtained from ground samples after reacting with $100 \% \mathrm{H}_{3} \mathrm{PO}_{4}$ at $25^{\circ} \mathrm{C}$ for at least 1 hour. Isotopic composition of the released $\mathrm{CO}_{2}$ was determined by using a Finnigan DELTA Plus Advantage mass spectrometer at the University of Brasília. Measurements were made against PDB standards for $\delta^{13} \mathrm{C}$ and $\delta^{18} \mathrm{O}$. Analytical reproducibility of $\delta^{13} \mathrm{C}$ and $\mathrm{d}^{18} \mathrm{O}$ values, based on replicas of NBS-19 standards, was better than $\pm 0.1 \%$.

The acquisition of new material for paleontological and stratigraphic research was performed along new section measurements, laboratory analyses and photos of specimens in all Corumbá Group outcrops. The classical outcrops, where studies have been focused, are the quarries of Laginha (Tamengo and Guaicurus formations) and of Corcal (Tamengo and Guaicurus formations), Porto Morrinhos (Bocaina Formation) and at Sobramil Port 
(Tamengo Formation), all of them nearby or located within the city of Corumbá. The present study shows new data from the Tamengo Formation in Cacimba section, near downtown Corumbá.

Several specimens of Corumbella were analyzed at the Laboratório de Micropaleontologia, Institute of Geoscience, University of Brasília. It was performed using stereomicroscope accomplished to a photography system and petrographic microscope.

\section{The Precambrian fossil record of the Corumbà region}

The fossil record of the Corumbá region encompasses most of the categories of Precambrian fossils known worldwide. It includes microbialites, prokaryotic and eukaryotic microfossils, trace fossils, vendotaenids, as well as metazoans (Gaucher et al., 2003; MoraisSoares et al., 2013).

The fossil record of the Jacadigo Group remains poorly known. Up to date, only negative epirelief linear trace fossils were recovered in thin, iron-rich mudstone layers (Fig. 4g). Other microand macrostructures are under investigation. On the other hand, a significant fossil record comes from the upper half of the Corumbá Group, including the phosphatized dolostones of the top of the Bocaina Formation and the limestones and siltstones of the Tamengo Formation. These fossils have been known since the 1950's (e.g. Beurlen and Sommer, 1957) and since then, some advances have been reached concerning the paleobiology of the Corumbá Group, and, therefore, documenting the diversity at the end of the Ediacaran Period (Fairchild et al., 2012; Gaucher et al., 2003; Kerber et al., 2013; Morais, 2013).

The protistan Titanotheca coimbrae (Gaucher and Sprechmann, 1999) was identified in the dolostones of the Bocaina Formation (Fig. 4d). Its biological affinity was demonstrated to be a foraminifer, and thus this record may represent one of the oldest occurrences of this group. Its importance lies in the fact that this fossil allows lithostratigraphic correlations between the Corumbá Group, the Holgart Formation (Port Nolloth Group) in Namíbia, and the Yerbal Formation (Arroyo del Soldado Group) in Uruguay, as well it allows paleogeographical reconstructions for the time of the amalgation of Gondwana at the end of the Neoproterozoic (Boggiani et al., 2010).

The fossil content of the Bocaina Formation also includes laminites, oncoids, domical and columnar stromatolites recovered in a series of outcrops distributed in the Corumbá region and almost $100 \mathrm{~km}$ to the south. These microbialites allowed to trace back variations in the eustatic levels and, thus, reconstruct the paleoenvironmetal mosaic that was present during the deposition of the Bocaina Formation (Morais, 2013).

The Tamengo Formation records the most important fossil content of Neoproterozoic of Brazil. It includes the Cloudina lucianoi (Beurlen and Sommer, 1957), reassigned from Aulophycus by Zaine and Fairchild, 1985 and Cloudina waldei (Hahn and Pflug, 1985), both recovered from grainstones beds (Figs. 3 and $4 \mathrm{e}-\mathrm{f}$ ). The genus Cloudina (Germs, 1972) was suggested as an index fossil of the Late Ediacaran (Grant, 1990). According to Amthor et al. (2003), the Cloudina species became extinct by the end of Ediacaran. Later on, a record of Cloudina ex. Gr. C. riemkeae (Germs, 1972) was reported from earliest Cambrian strata in Siberia co-occurring with Anabarites trisulcatus Voronova and Missarzhevsky, 1969 (Zhuravlev et al., 2009). Later, occurrences of anabaritid species were interpreted as uppermost Ediacaran (Zhuravlev et al., 2012; Fig. 2D) from Siberian samples. Despite this apparent controversy, it is important to point out that, if evolution of species is considered, among the seven species of the genus Cloudina, one might be ancestral and, so, distinct timing of appearance and extinction for different species would be expected.
Corumbella werneri (Hahn et al., 1982; Fig. 4a-b) also occurs in the Tamengo Formation, and has been interpreted as a cnidarian, possibly related to the Scyphozoa (Hahn et al., 1982; Walde et al., 1982; Babcock et al., 2005). Van Iten et al. (2014) interpreted this fossil as a colunariid scyphozoan, related to other non-erect Ediacaran fossils such as the vendozoan genera Phyllozoon (Jenkins and Gehling, 1978) or Dickinsonia (Sprigg, 1947). Since, in 2012 , three-dimensional specimens of Corumbella werneri were found together with two-dimensionally preserved material in a quarry on the western edge of Corumba, it is evident that this species does not belong to the conulariids, but to cloudinids (personal comm. Steiner to Erdtmann, 2012).

A series of micro- and macrofossils of uncertain affinities (Incertae Sedis) were also recovered in the Cerradinho, Tamengo and Guaicurus formations (Gaucher et al., 2003). These include the enigmatic chuarids Chuaria circularis (Walcott, 1899) and Tawuia sp. (Gaucher et al., 2003; Pacheco, 2012), and different species of leiosphaerids, as well Myxococcoides sp. and Soldadophycus bossii (Gaucher et al., 1996; Gaucher et al., 2003). Cyanobacteria were recovered in palynological preparates and are represented by Bavlinella faveolata (Schepeleva) (Vidal, 1976); Siphonophycus robustum (Schopf, 1968) emended Butterfield et al. (1994); and Eoentophysalis croxfordii (Muir, 1976) emended Butterfield et al. (1994) (Gaucher et al., 2003). Rare vendotaenids as Eoholynia corumbensis (Gaucher et al., 2003; see Fig. 4c for the genus) and Vendotaenia antiqua (Gnilovskaya, 1971) were recovered from finegrained beds of the Guaicurus Formation. E. corumbensis can be easily observed in hand samples, while $V$. antiqua was found only in palynological dissolution.

The fossil record of the Tamengo Formation is the most remarkable when compared to the other units of the Jacadigo and Corumbá groups. As pointed out by Fairchild et al. (2012) and Morais-Soares et al. (2013), the macrofossils of this unit can help to shed light on evolutionary aspects of the early metazoans, as well as to understand the environmental changes and its implications over the biota at the end of the Ediacaran. New researches, mainly the non-destructive types, have been developed aiming to access high resolution details of skeletons and shells in order to answer such open questions (Kerber et al., 2013).

\subsection{On Cloudina lucianoi (Beurlen and Sommer, 1957)}

At the present, the genus Cloudina (Germs, 1972) has seven species:

- Cloudina lucianoi (Beurlen and Sommer, 1957) (Tamengo Formation, Brazil);

- Cloudina hartmannae (Germs, 1972) (Nama Group, Namibia);

- Cloudina riemkae (Germs, 1972) (Nama Group, Namibia);

- Cloudina waldei (Hahn and Pflug, 1985) (Tamengo Formation, Brazil);

- Cloudina lijiagouensis (Zhang, Li and Dong, 1982) (Yangtzé Platform, China);

- Cloudina sinensis (Zhang et al., 1982) (Yangtzé Platform, China);

- Cloudina carinata (Cortijo et al., 2010) (Spain; Table 1).

These seven species are restricted to Ediacaran strata, although early Cambrian specimens were reported in Russian successions. However, later, these Cambrian occurrences were re-interpreted as Ediacaran, as pointed below. Two of these have a worldwide distribution: Cloudina hartmannae and Cloudina riemkeae.

Two species have been recognized in South America: C. lucianoi and $C$. riemkeae. Cloudina riemkeae was originally described from Namibia and later has been also recorded from Uruguay (Gaucher et al., 2003) and from Russia (Zhuravlev et al., 2012). Cloudina lucianoi has occurrences in Brazil (Beurlen and Sommer, 1957; 

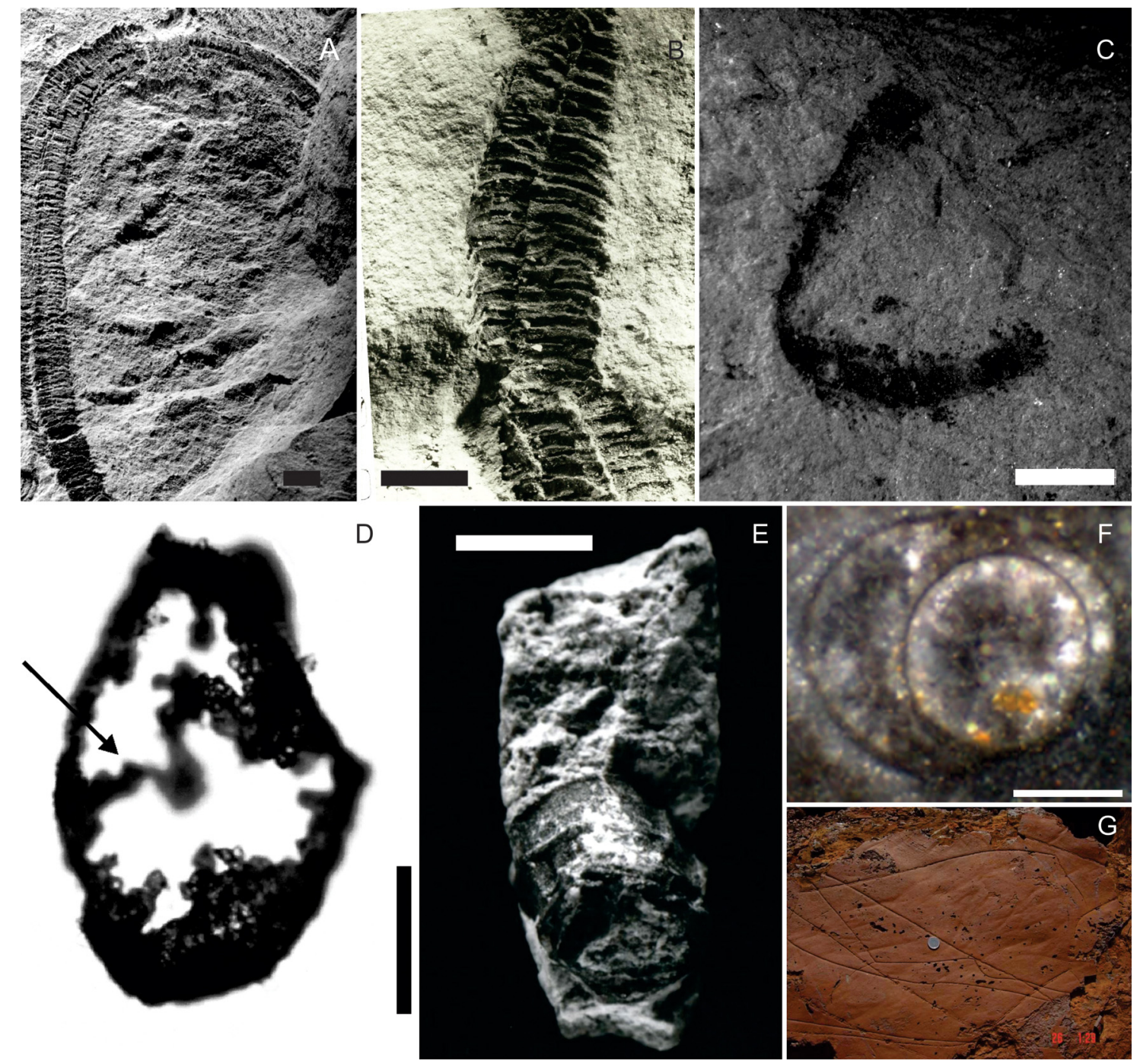

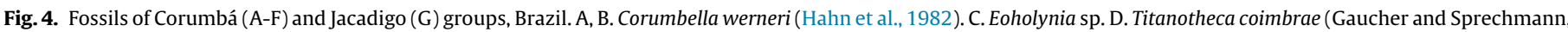

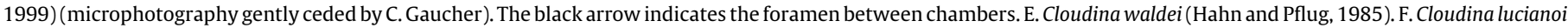
(Beurlen and Sommer, 1957). G. Trace fossils. Scales: $4 \mathrm{~cm}$ in A, $1 \mathrm{~cm}$ in B, $2 \mathrm{~cm}$ in C and E, $25 \mu \mathrm{m}$ in D and $500 \mu \mathrm{m}$ in F. Coin in G is about $2 \mathrm{~cm}$ in diameter.

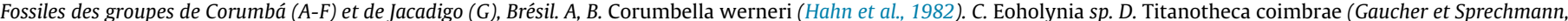

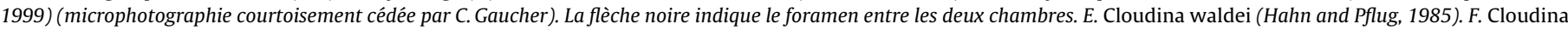

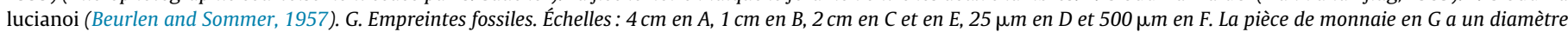
d'environ $2 \mathrm{~cm}$.

Zaine and Fairchild, 1985; Gaucher et al., 2003; Boggiani et al., 2010) and in the Ediacaran Itapucumi Group of Paraguay (Warren et al., 2011).

The species Cloudina lucianoi discussed in this paper was originally described as Aulophycus lucianoi (Beurlen and Sommer, 1957), whose type-material came from the Corumbá Limestone and was sampled at the type-locality between Ladário and Corumbá cities, State of Mato Grosso do Sul, and is housed at Earth Sciences
Museum (Rio de Janeiro, Brazil), which allowed access for the present study (Figs. 4F, 5).

The original paper by Beurlen and Sommer (1957) was published in a local Brazilian journal in Portuguese language. Later on, the close similarity with Cloudina was recognized by Zaine and Fairchild (1985), and a new description and diagnosis for Cloudina lucianoi was published also in Portuguese. Both diagnosis, the original one by Beurlen and Sommer (1957) and the one by Zaine

Table 1

Species of Cloudina (Germs, 1972) and their original provenance in Ediacaran system from several countries.

Espèces de Cloudina (Germs, 1972) et provenance originelle dans le Système Ediacarien de différents pays.

\begin{tabular}{|c|c|c|}
\hline Cloudina lucianoi (Beurlen and Sommer, 1957) & BRAZIL & Tamengo Formation, Corumbá Group \\
\hline Cloudina hartmannae (Germs, 1972) & NAMIBIA & Omkyk Member, Zaris Formation, Zaris Basin \\
\hline Cloudina riemkeae (Germs, 1972) & NAMIBIA & Omkyk Member, Zaris Formation, Zaris Basin \\
\hline Cloudina waldei (Hahn and Pflug, 1985) & BRAZIL & Tamengo Formation, Corumbá Group \\
\hline Cloudinalijiagouensis (Zhang et al., 1992) & CHINA & Dengying Formation, Sinian System \\
\hline Cloudinasinensis (Zhang et al., 1992) & CHINA & Dengying Formation, Sinian System \\
\hline Cloudina carinata (Cortijo et al., 2010) & SPAIN & Membrillar Member, Ibor-Navalpino Group \\
\hline
\end{tabular}

Please cite this article in press as: Walde, D.H.G., et al., New aspects of Neoproterozoic-Cambrian transition in the Corumbá region (state of Mato Grosso do Sul, Brazil). Annales de Paléontologie (2015), http://dx.doi.org/10.1016/j.annpal.2015.07.002 


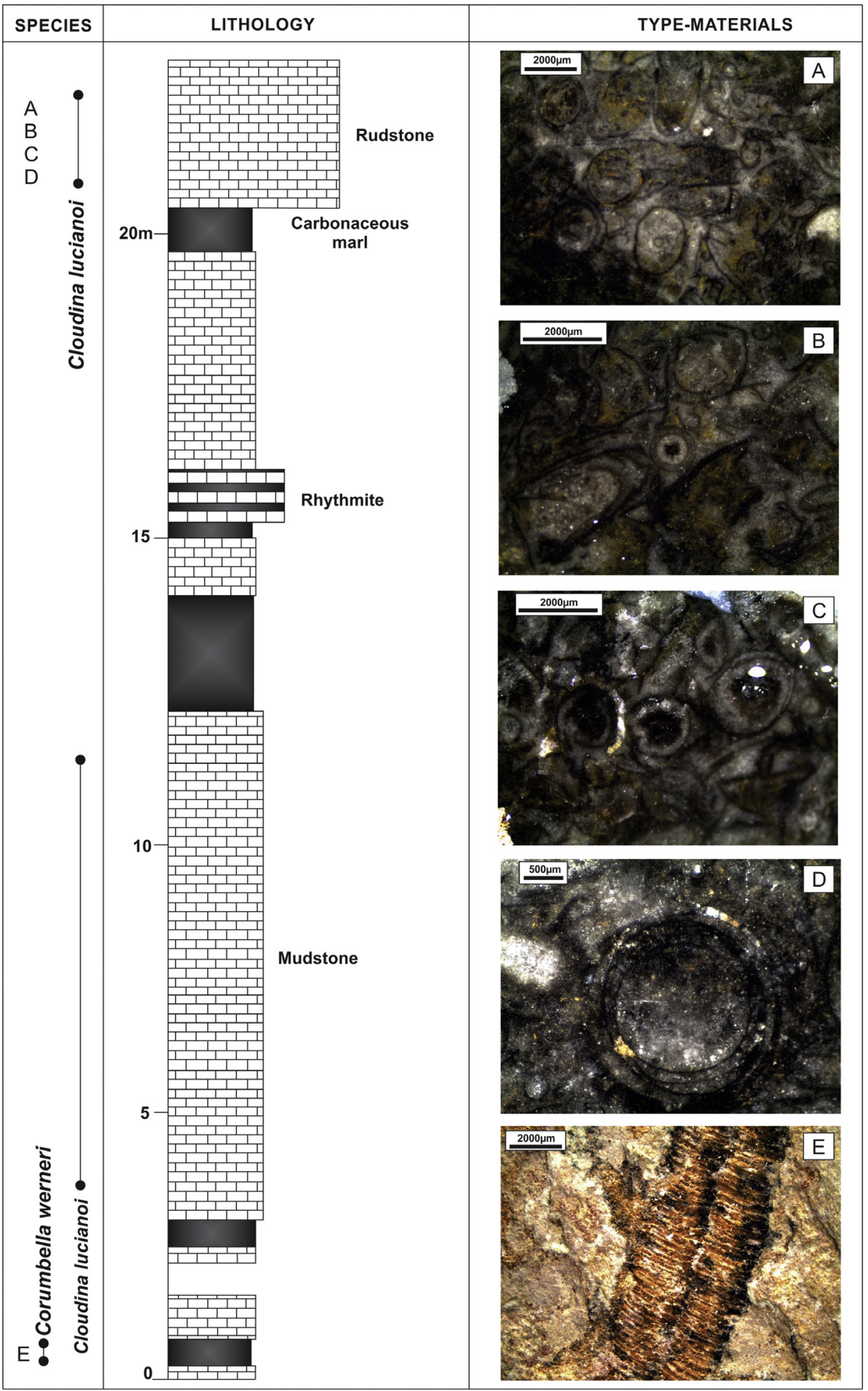

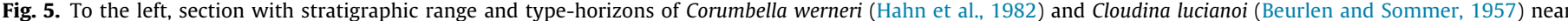

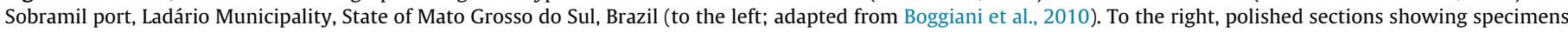

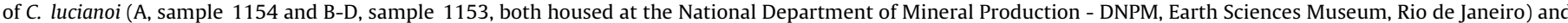

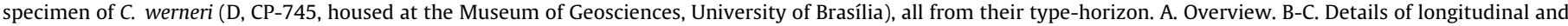
transversal sections. D. Transverse sections showing a cone-in-cone structure. E. Corumbella werneri (details).

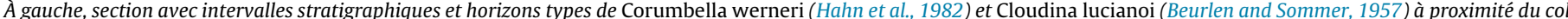

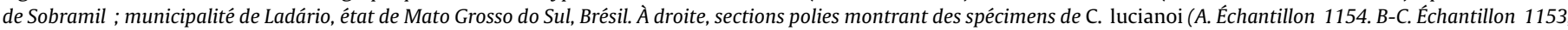

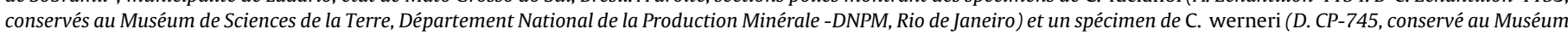

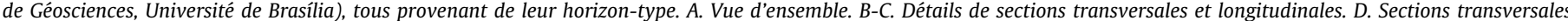
montrant une structure de cônes emboîtés. E. Corumbella werneri (détails). 
and Fairchild (1985), emphasized size variations of the exoskeleton of the species nowadays referred to Cloudina lucianoi. It is pointed out herein that the clear cone-in-cone characteristic for the genus is used to keep this species as a member of Cloudina. Generally, species of Cloudina have a layered cone-in-cone exoskeleton which differs from the tubular shaped skeleton species of the carbonatic algae Aulophycus (Fenton and Fenton, 1939). Cloudina waldei (Hahn and Pflug, 1985) described from the same locality of the Tamengo Formation was considered by Zaine and Fairchild (1985) as a junior synonym of Cloudina lucianoi, however, this inclusion of $C$. waldei cannot be considered as final.

The type-horizon of $C$. lucianoi was originally considered as Cambrian (Beurlen and Sommer, 1957), however, Zaine and Fairchild (1985) and Walde (1988) considered this type-horizon to be part of the uppermost Neoproterozoic Tamengo Formation. Boggiani et al. (2010) and Babinski et al. (2013), based on direct radiometric dating of detrital zircons, isotope and paleontological data, confirmed that this interval has to be placed into the Ediacaran.

Originally, the type-horizon for Cloudina lucianoi was positioned at the uppermost portion of the Tamengo Formation (Fig. 3), located several meters above the water-pumping station at the southern banks of the Paraguay River (Beurlen and Sommer, 1957), in the locality known as Sobramil Port. As shown by Walde (1988) and Boggiani et al. (2010) in the Sobramil Port area, Cloudina lucianoi first occurs above the occurrences of Corumbella werneri (Hahn et al., 1982) and disappears close to the uppermost Tamengo Formation. Two-dimensional specimens of Corumbella werneri commonly occur in siliciclastic sediments, mainly pelites, whereas Cloudina lucianoi occurs in limestones. Recent geological investigations in October 2012, as well as during the Corumbá Meeting in August 2013, demonstrated the occurrence of $C$. werneri together with Cloudina lucianoi at the Corcal quarry at a higher stratigraphic level of the Tamengo Formation.

It is important to point out that the type-horizon for Corumbella werneri was also positioned in outcrop of the Tamengo Formation located at the Sobramil Port area (Fig. 5), close to the type-locality for Cloudina lucianoi. Both species occur in the same succession also in Itapucumi Group in Paraguay (Warren et al., 2011).

At the present date, a revision of Cloudina lucianoi is under investigation as well as a detailed comparison with the six other Cloudina species. The seven species are considered to be restricted to the Ediacaran period. Some of these species may be synonymized. Valid species may possess a distinctive skeleton structure and their first appearance (FAD) and extinction (LAD) may not have occurred at the same time. Therefore, the projected taxonomic revision, which is being conducted, may contribute to improve the Ediacaran biostratigraphy.

Warren et al. (2014) referred to undetermined species of Cloudina in strata of the Bambuí Group, possibly the Sete Lagoas Formation, State of Minas Gerais, Brazil. When the species identification has been completed, this new occurrence of Cloudina sp. in Minas Gerais may open a new perspective for biostratigraphic correlation between strata of Terminal Neoproterozoic in Brazil as well as abroad.

\subsection{On biological affinities of Corumbella werneri (Hahn et al., 1982)}

Since its discovery, the systematic position of Corumbella werneri (Hahn et al., 1982) has been controversial with regard to its phylogenetic relations and its mode of fossilization as well as its original mode of life (Babcock et al., 2005). Based on several similar morphological traits, $C$. werneri was compared to Stephanoscyphus, a "bundled" colony of recent multibranched cnidarian coronoiid polyps, by Hahn et al. (1982) and (with modifications) by Babcock et al. (2005). Despite some morphological similarities of Stephanoscyphus with $C$. werneri, a phylogenetic and taxonomic relationship appears to be unlikely. Basically, two major reconstruction models have been proposed for $C$. werneri so far:

- an erect or semi-erect tubular life mode (Hahn et al., 1982; Babcock et al., 2005) with a phylogenetic-taxonomic assignment to coronoid scyphozoans and a systematic association of C. werneri to conulariid scyphozoans by Babcock et al. (2005), Pacheco (2012), and Van Iten et al. (2014);

- a sea bottom attached semi-tubular life mode with a probable "open" phylogenetic relationship to other non-erect Ediacaran fossils such as the vendozoan genera Phyllozoon or Dickinsonia (Zaine and Fairchild, 1985; Erdtmann, 2004).

However, Phyllozoon is only known as an imprint without any test or shell. Both systematic assignments as colunariids and as vendozoans are now rejected resulting from the current analysis of 3-D preserved material.

A distal tetragonal "crown" was postulated originally by Hahn et al. (1982), then by Babcock et al. (2005) and by Pacheco et al. (2011) to have existed and later was also refigured by Pacheco (2012) (Fig. 4B). No "head-crown" or parts of it, however, were observed by the present authors. A conulariid phylogenetic and thus taxonomic relationship cannot be verified herein because all materials collected by these authors do not substantiate any tetragonal cross-sectional diameter, but instead, an original (pre-compression) consistently circular transverse cross-section of these tuboid forms. As already proposed by Cai et al. (2014), the general morphology of cloudinids suggests a functional ecological relationship of these fossils to Recent pogonophoran "tube worms", what would place them as an analogous in terms of functional biology, in terms an extremely low oxygen-dependent strategy, with sessile bottom-dwelling group of fossils.

\section{Results and discussion}

\subsection{On new observations on mineralogical and chemical aspects of the Corumbà Group}

The Corumbella-bearing massive siltstone contains euhedral and corroded crystals of quartz. It overlays a meter of siltstone and shale planar laminae and is recovered by rhythmite, which presents, under microscope, some microbial mats, cracked laminae, and thin sections of prismatic calcite interpreted as pseudomorphs over gypsum crystals. All the rocks present fractures commonly filled by calcite or gypsum. The mineralogical analysis determined by XRD (Fig. 6c4), pointed for all pelitic whole rocks to be constituted mainly by quartz, muscovite, smectite and chlorite. Calcite and gypsum are major constituents in some layers. Smectite and illite are the main constituents of the clay fraction, whereas chlorite is a minor constituent, and quartz is scarce, except in the levels containing gypsum, where it is a main constituent in both whole rock and clay fraction. Dark gray calcarenites, strongly recrystallized, are comprised by calcite, whereas quartz and smectite are minor or trace constituents. The basal level of the limestone is a fossiliferous grainstone with bioclasts of Cloudina, which can be seen in thin sections (Figs. 6c1 to $c 3$ ).

The isotopic results obtained for the Cacimba Section show a range from $-11.9 \%$ to $-9 \%$ for $\delta^{18} \mathrm{O}$ and -8 to $+6 \%$ for $\delta^{13} \mathrm{C}$ (Fig. 6b).

The basal level of mudstone with microbial mats, cracked laminae, and calcite pseudomorphs over gypsum crystals indicates episodic events of fine detrital deposition under shallow to 


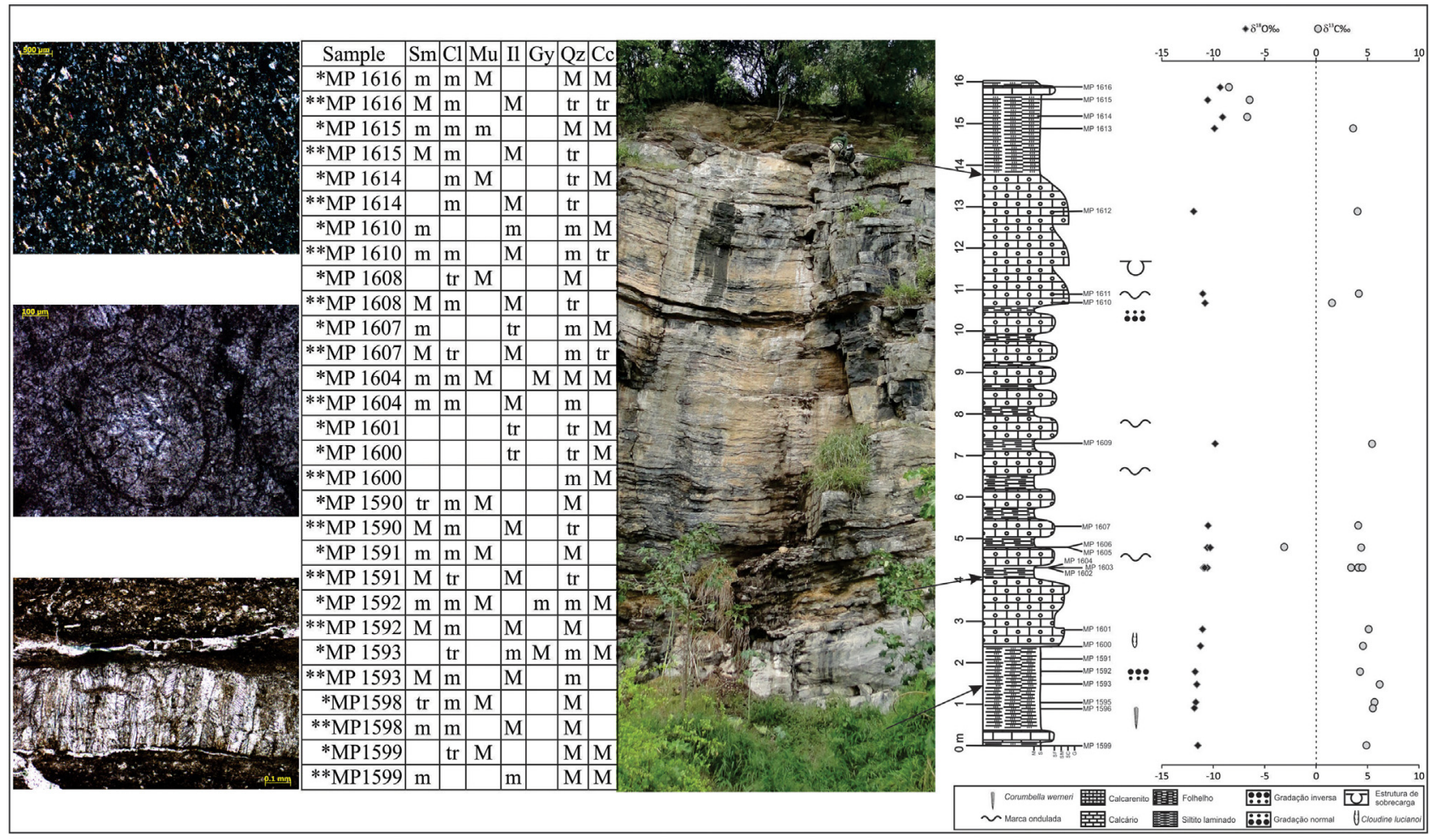

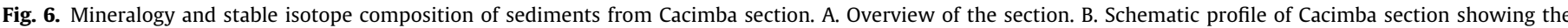

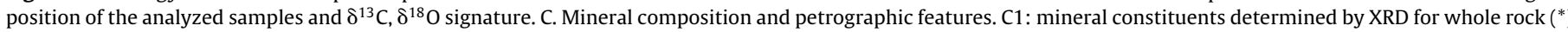

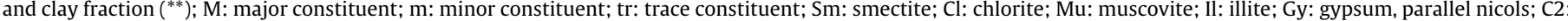

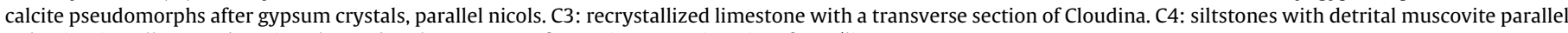
to lamination. Illustrated sections housed at the Museum of Geosciences, University of Brasília.

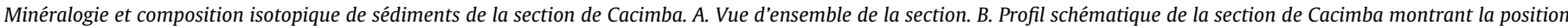

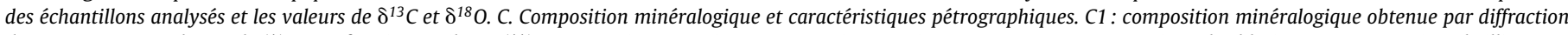

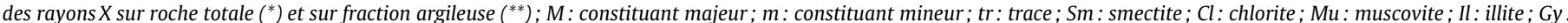

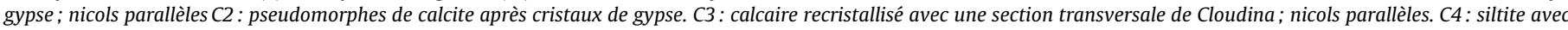
muscovite détritique parallèle à la lamination. Sections illustrées conservées au Muséum de Géosciences, Université de Brasília.

intertidal marine conditions. Smectite as a major constituent of the whole rock and clay fraction suggests a deposition of thin sediments containing significant amounts of unstable material, such as volcanic ash. This assumption is supported by the presence of chlorite.

In the studied section, Corumbella was found only at the basal level of the Tamengo Formation at the Cacimba outcrop and may be associated with episodic events of burial, or even water quality changes driven by the interaction with the volcanic material.

These basal limestones are mainly bioclastic beds in which Cloudina is a common constituent. Narrow, high and symmetrical peaks of illite and chlorite characterize a late diagenesis, but the important amount of smectite may have been preserved thanks to a potassium deficit, or telodiagenesis.

Concerning the isotopic data, in a general view, the section shows a consistent trend for the values of $\delta^{18} \mathrm{O}$, with less negative values toward the top. However, when we analyze the results in terms of absolute values for $\delta^{18} \mathrm{O}$, it is noteworthy that most of the values are between $-10 \%$ and $-11 \%$, suggesting that its primary signature has changed. In fact, such values of $\delta^{18} \mathrm{O}$ found for the most part of the section suggest that the oxygen isotope signature reflects a diagenetic modification. For the carbon isotope, the record shows coherent and phased changes corresponding to the stratigraphic variations (Fig. 6b). In the studied section, the $\delta^{13} \mathrm{C}$ profile shows a wide variation from very positive values (+6\% vs. PDB standard) to very negative values (up to $-8 \%$ ) towards the top.
In previous works (Boggiani et al., 2010; Spangenberg et al., 2014), $\delta^{13} \mathrm{C}$ values vary from negative values (up to $-2 \%$ ) at the base of the Tamengo Formation and become positive towards the top. The $\delta^{13} \mathrm{C}$ values as negatives as $-8 \%$ for this succession have never been reported before. The sediments exposed at the Cacimba Section correspond to the upper part of the Tamengo Formation. That section is characterized by the co-occurrence of Corumbella and Cloudina in the lower portion of the outcrop, where $\delta^{13} \mathrm{C}$ values are positive. The negative excursion with $\delta^{13} \mathrm{C}$ values up to $-8 \%$ is placed at the top of the section, where no fossils were collected due to the steep grade of this Cacimba Cliff section. However, an occurrence of Corumbella-Cloudina can be predicted at the higher level of the Tamengo Formation also at the Cacimba section because of a coeval main occurrence of these fossils at the nearby Corcal section and at Sobramil Port. This negative excursion is apparently in agreement with the late Ediacaran carbon cycle at the PrecambrianCambrian boundary (e.g. Narbonne et al., 1994; Amthor et al., 2003; Ishikawa et al., 2008).

\subsection{On new consideration of paleontology}

The significance of the tuboid fauna of the Tamengo Formation in the Corumbá region is highlighted by two important aspects:

- paleoecologically, Corumbella werneri together with Cloudina lucianoi documents a shallow marine sea bottom suspension 
feeding biota (see Cai et al., 2014), which indicates a high degree of oxygen depletion (see Spangenberg et al., 2014);

- stratigraphically, this fauna correlates well with a very similar biota along the northern edge of the Yangtze Platform in China and probably with hyponymous fossils in Namibia, North America, Spain, Siberia and other parts of the world.

This makes this cloudinid assemblage a first true global "Index Fossil Assemblage" and a strong contender for global correlatability of the Phanerozoic. Keeping in mind that the occurrence of a "tuboid or cloudinid assemblage" worldwide initiates a regressive (probably a bipolar glacially induced) trend, concomittant with hydrospheric oxygen depletion, this cloudinid group of fossils, regardless of their phylogenetic status, would present a suitable marker for the beginning of the Phanerozoic Eon. Considering that on the South China Plate as well as in many other sections worldwide, an eustatic (glacigenic) hiatus, possibly several hiati, exists at the currently defined Precambrian-Cambrian boundary a potential redefinition of this boundary at this lower (now terminal Ediacaran) level might be suggested.

\section{Final remarks}

Isotope signal of Cacimba section presented herein suggests a latest Ediacaran deposition, in a context of volcanic activity, what can lead to exceptional fossil preservation. These new data significantly document the still discussed Neoproterozoic-Cambrian transition in South America. Moreover, no section worldwide documents a depositionally and biostratigraphically uninterrupted succession across the Ediacaran-Cambrian boundary except (perhaps) the Fortune Head section of eastern Newfoundland (Brasier et al., 1994; Landing, 1994; Babcock et al., 2014). This section currently contains the GSSP for the lower boundary of the Cambrian System, including a biological document composed exclusively by trace fossils. These trace fossils (or any behaviorally mediated paleoecological signals) do not document a vectorial evolutionary trend and cannot be regarded to mark any intersystemic boundary according to the IUGS Code. Babcock et al. (2014) encourage search for an alternative stratigraphic horizon, but do not advocate any alternative for the Ediacaran-Cambrian boundary should be considered to be placed at a level below the glacigenically induced Nomtsas-Baykonurian hiati (Chumakov, 2009; Germs and Gaucher, 2012). Such terminal Ediacaran sections for a new potential Cambrian GSSP are observed in Brazil and are also documented worldwide.

It is here proposed to adopt a new Cambrian GSSP within a continuous section marked by the first occurrence of a widespread, taxonomically well-defined cloudinid species.

\section{Disclosure of interest}

The authors declare that they have no conflicts of interest concerning this article.

\section{Acknowledgments}

The authors are grateful to Brazilian Petroleum S.A. - PETROBRAS - and National Agency for Petroleum, Gas and Biofuels - ANP - for granting and to FINATEC for administrative support of the project EDIACARIANO, grant No. 0050.0071326.11.9. To Claudio Gaucher (National University of Uruguay) and to Paulo C. Boggiani for important discussions and for advice re stratigraphy of the Corumbá Group. Essential assistance in the field was given by Felisberto Santiago (Engermix) and Aguinaldo Silva (UFMS), to Matheus Denezine for the photographs of the polished sections.
Dermeval do Carmo thanks especially to Gerard and Alta Germs for important discussions on Cloudina, support during field work, as well as for their friendship, and also thanks to Hong Hua and to Yaoping Cai (Northwestern University, Xi'an, China). Comparisons with species from Namibia were made possible through the curators of the South African Museum, Cape Town, South Africa. Thanks are due to Gabi Schneider, H. Mocke and the geologist R. Muyamba of the Namibian Geological Survey, who enabled Dermeval do Carmo to attend a field trip in Namibia, this having focused on visiting and describing the type-horizon of Cloudina hartmannae and Cloudina riemkeae supervised by G. Germs.

\section{References}

Alvarenga, C.J.S., Boggiani, P.C., Babinski, M., Dardene, M.A., Figueiredo, M.F., Santos, R.V., Dantas, E.L., 2009. The Amazonian Palaeocontinet. In: Gaucher, C., Sial, A.N., Frimmel, H., Halverson, G.P. (Eds.), Neoproterozoic-Cambrian Tectonics, Global Changes and Evolution: A focus on Southwestern Gondwana, 16. Elsevier, Amsterdam, pp. 15-28.

Amthor, J.E., Grotzinger, J.P., Schröder, S., Bowring, S.A., Ramezani, J., Martin, M.W. Matter, A., 2003. Extinction of Cloudina and Namacalathus at the PrecambrianCambrian boundary in Oman. Geology 31, 431-434.

Babcock, L.E., Grunow, A.M., Sadowski, G.R., Leslie, S.A., 2005. Corumbella, an Ediacaran-grade organism from the Late Neoproterozoic of Brazil. Palaeogeography. Palaeoclimatology, Palaeoecology 220, 7-18.

Babcock, L.E., Peng, S.-C., Zhu, M.-Y., Xiao, S.-H., Ahlberg, P., 2014. Proposed reassessment of the Cambrian GSSP. Journal of African Earth Sciences 98, 3-10.

Babinski, M., Boggiani, P.C., Trindade, R.I.F., Fanning, C.M., 2013. Detrital zircon ages and geochronological constraints on the Neoproterozoic Puga diamictites and associated BIFs in the southern Paraguay Belt, Brazil. Gondwana Research 23 (3), 988-997.

Beurlen, K., Sommer, F.W., 1957. Observações estratigráficas e paleontológicas sobre o calcário Corumbá. Boletim de Geologia e Mineralogia-DNPM 168, 1-35.

Boggiani, P.C., Gaucher, C., Sial, A.N., Babinski, M., Simon, C.M., Riccomini, C., Ferreira, V.P., Fairchild, T.R., 2010. Chemostratigraphy of the Tamengo Formation (Corumbá Group, Brazil): a contribution to the calibration of the Ediacaran carbon-isotope curve. Precambrian Research 182, 382-401.

Brasier, M.D., Cowie, J., Taylor, M., 1994. Decision on the Precambrian-Cambrian boundary. Episodes 17, 95-100.

Cai, Y., Hua, H., Schiffbauer, J.D., Sun, B., Yuan, X., 2014. Tube growth patterns and microbial mat-related lifestyles in the Ediacaran fossil Cloudina, Gaojiashan Lagerstätte, South China. Gondwana Research 25, 1008-1018.

Chumakov, N.M., 2009. Neoproterozoic glacial events in Eurasia. In: Gaucher, C., Sial, A.N., Halverson, Frimmel, G.P., H.E. (Eds.), Developments in Precambrian Geology, Neoproterozoic-Cambrian Tectonics, 16. Global Change and Evolution, pp. 389-403.

Erdtmann, B.-D., 2004. The Infra-Cambrian bioradiation event: a review from the perspective of the Yangtze Plate in South China and correlation with coeval strata in Brazil. Revista Brasileira de Paleontologia 7 (2), 223-230.

Fairchild, T.R., Sanchez, E.A.M., Pacheco, M.L.A.F., Leme, J.M., 2012. Evolution of Precambrian life in the Brazilian Geological Record. International Journal of Astrobiology 11, 309-323.

Fedonkin, M.A., 2003. The origin of the Metazoa in the light of the Proterozoic fossil record. Palaeontological Research 7, 9-41.

Fike, D.A., Grotzinger, J.P., Pratt, L.M., Summons, R.E., 2006. Oxidation of the Ediacaran Ocean. Nature 444, 744-747.

Gaucher, C., Boggiani, P.C., Sprechmann, P., Sial, A.N., Fairchild, T.R., 2003. Integrated correlation of the Vendian to Cambrian Arroyo del Soldado and Corumbá Group (Uruguay and Brazil): palaeogeographic, palaeoclimatic and palaeobiologic implications. Precambrian Research 120, 241-278.

Germs, G.J.B., Gaucher, C., 2012. Nature and extent of a late Ediacaran (ca. 547 Ma) glacigenic erosion surface in southern Africa. South African Journal of Geology 115, 91-102.

Grant, S.W.F., 1990. Shell structure and distribution of Cloudina, a potential index fossil for the terminal Proterozoic. American Journal of Science 290-A, 261-294.

Hahn, G., Hahn, R., Leonardos, O.H., Pflug, H.D., Walde, D.H.G., 1982. Körperlich erhaltene Scyphozoen-Reste aus dem Jungpräkambrium Brasiliens. Geologica et Paleontologica 16, 1-18.

Hoffman, P.F., Kaufman, A.J., Halverson, G.P., Schrag, D.P., 1998. A Neoproterozoic Snowball Earth. Science 281, 1342-1346.

Ishikawa, T., Ueno, Y., Komiya, T., Sawaki, Y., Han, J., Shu, D., Li, Y., Maruyama, S., Yoshida, N., 2008. Carbon isotope chemostratigraphy of a Precambrian/Cambrian boundary section in the Three Gorge area, South China: prominent global-scale isotope excursions just before the Cambrian Explosion. Gondwana Research 14, 193-208.

Jones, J.P., 1985. The southern border of the Guapore Shield in western Brazil and Bolivia: an interpretation of its geological evolution. Precambrian Research 28, $111-135$.

Kerber, B.B., da Rosa, A.L.Z., Gabas, S.G., Leme, J.M., Pacheco, M.L.A.F., 2013. O registro fossilífero de metazoários ediacaranos na América do Sul e suas implicações nos estudos sobre origem e complexificação da vida animal. Geología USP- Série Científica 13, 5-64. 
Landing, E., 1994. Precambrian-Cambrian boundary global stratotype ratified and a new perspective of Cambrian time. GSA Geology 28, 143-146.

Li, Z.X., Evans, D.A., Halverson, G.P., 2013. Neoproterozoic glaciations in a revised global palaeogeography from the breakup of Rodinia to the assembly of Gondwanaland. Sedimentary Geology 294, 219-232.

Mills, D.B., Canfield, D.E., 2014. Oxygen and animal evolution: Did a rise of atmospheric oxygen "trigger" the origin of animals? BioEssays 36, $1145-1155$.

Morais, L.P.C., 2013. Paleobiologia da Formação Bocaina (Grupo Corumbá), Ediacariano, Mato Grosso do Sul. Master’s Dissertation. Universidade de São Paulo, 131 p. [Unpublished].

Morais-Soares, L.P.C., Kerber, B.B., Osés, G.L., Oliveira, A.M., Pacheco, M.L.A.F., 2013. Paleobiologia e Evolução: o potencial do registro fossilífero brasileiro. Revista Espinhaço 2, 24-40.

Narbonne, G.M., Kaufman, A.J., Knoll, A.H., 1994. Integrated chemostratigraphy and biostratigraphy of the Windermere Supergroup, northwestern Canada: Implications for Neoproterozoic correlations and the early evolution of animals. Geological Society of America Bulletin 106, 1281-1292.

Och, L.M., Shields-Zhou, G.A., 2012. The Neoproterozoic oxygenation event: environmental perturbations and biogeochemical cycling. Earth-Science Reviews 110, 26-57.

Pacheco, M.L.A.F., 2012. Reconstituição morfológica e análise sistemática de Corumbella werneri (Hahn et al., 1982) (Formação Tamengo, Ediacarano, Grupo Corumbá), Mato Grosso do Sul, Brasil: implicações paleoecológicas e tafonômicas. Universidade de São Paulo, PhD thesis Univesidade de Sao Paulo, 170 p. [Unpublished].

Pacheco, M.L.A.F., Leme, J.M., Machado, A.F., 2011. Taphonomic analysis and geometric modeling for the reconstitution of the Ediacaran metazoan Corumbella werneri Hahn et al., 1982 (Tamengo Formation, Corumbá Basin, Brazil). Journal of Taphonomy 9, 269-283.

Piacentini, T., Vasconcelos, P.M., Farley, K.A., 2013. ${ }^{40} \mathrm{Ar} /{ }^{39} \mathrm{Ar}$ constraints on the age and thermal history of the Urucum Neoproterozoic banded iron-formation, Brazil. Precambrian Research 228, 48-62.
Spangenberg, J.E., Bagnoud-Velasquez, M., Boggiani, P.C., Gaucher, C., 2014. Redox variations and bioproductivity in the Ediacaran: evidence from inorganic and organic geochemistry of the Corumbá Group, Brazil. Gondwana Research 26 1186-1207.

Trompette, R., Alvarenga, C.J.S., Walde, D.H.G., 1998. Geological evolution of the Neoproterozoic Corumbá Graben System, Brazil: Depositional context of the stratified Fe and Mn ores of the Jacadigo Group. Journal of South American Earth Sciences 11, 587-597.

Van Iten, H., Marques, A.C., Leme, J.M., Pacheco, M.L.A.F., Simões, M.G., 2014. Origin and early diversification of the phylum Cnidaria Verrill: major developments in the analysis of the taxon's Proterozoic-Cambrian history. Palaeontology 57 677-690.

Walde, D.H.G., 1988. Das Proterozoische Paraguay-Araguaia orogen in WestBrasilien, ausgehend von Untersuchungen im Raum Corumbá. Habil. Schrift. Albert-Ludwigs-Universität, Freiburg, 122 p.

Walde, D.H.G., Leonardos, O.H., Hahn, G., Pflug, H.D., 1982. The first Pre-Cambrian megafossils from South America, Corumbella werneri. Anais da Academia Brasileira de Ciências 54, 461.

Warren, L.V., Fairchild, T.R., Gaucher, C., Boggiani, P.C., Poiré, D.G., Anelli, L.E. Inchausti,J.C.G., 2011. Corumbella and in situ Cloudina in association with thrombolites in the Ediacaran Itapucumi Group, Paraguay. Terra Nova 23, 382-389.

Warren, L.V., Quaglio, F., Riccomini, C., Simões, M.G., Poiré, D.G., Strikis, N.M., Anelli, L.E., Strikis, P.C., 2014. The puzzle assembled: Ediacaran guide fossil Cloudina reveals an old proto-Gondwana seaway. Geology 42, 391-394.

Zaine, M.F., Fairchild, T.R., 1985. Comparision of Aulophycus lucianoi Beurlen and Sommer from Ladário (MS) and the genus Cloudina Germs, Ediacaran of Namibia. Anais da Academia Brasileira de Ciências 57, 130.

Zhuravlev, A.Y., Liñán, E., Vintaned, J.A.G., Debrenne, F., Fedorov, A.B., 2012. New finds of skeletal fossils in the Terminal Neoproterozoic of the Siberian Platform and Spain. Acta Palaeontologica Polonica 57, 205-224.

Zhuravlev, A.Y., Vintaned, J.A.G., Ivantsov, A.Y., 2009. First finds of problematic Ediacaran fossil Gaojiashania in Siberia and its origin. Geological Magazine 146 $775-780$. 